\title{
COVID-19 in Latin America: A Bibliometric Analysis of Scientific Publications in Health
}

\author{
Miguel Gallegos ${ }^{1,2,3 *}$, Mauricio Cervigni ${ }^{2,3}$, Andrés J. Consoli ${ }^{4}$, Tomás Caycho-Rodríguez ${ }^{5}$, \\ Fernando Andrés Polanco ${ }^{3,6}$, Pablo Martino ${ }^{2,3}$, Viviane de Castro Pecanha ${ }^{7}$, Carmen Burgos Videla ${ }^{8}$, \\ Roberto Polanco-Carrasco ${ }^{9}$, Adriana Marie Cusinato ${ }^{2,10}$
}

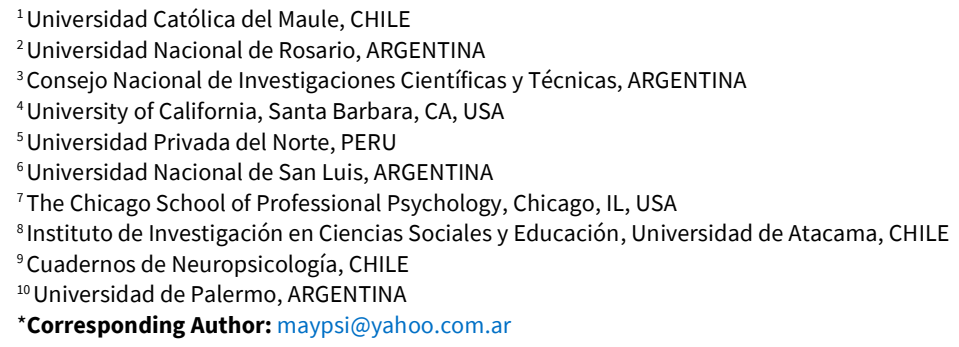

Citation: Gallegos M, Cervigni M, Consoli AJ, Caycho-Rodríguez T, Polanco FA, Martino P, de Castro Pecanha V, Burgos Videla C, Polanco-Carrasco R, Cusinato AM. COVID-19 in Latin America: A Bibliometric Analysis of Scientific Publications in Health. Electron J Gen Med. $2020 ; 17(6)$ :em261. https://doi.org/10.29333/ejgm/8460

\section{ARTICLE INFO}

Received: 2 Jun. 2020

Accepted: 22 Jul. 2020

\begin{abstract}
The coronavirus disease (COVID-19) has become a global health crisis. The scientific community has responded with a sizable level of research and publications, many of which are beginning to be identified and analyzed in systematic reviews of the literature and bibliometric studies. No readily identifiable, comparable study focused on Latin American scientific literature has been undertaken thus far. Therefore, this article analyzes such literature, focused on COVID-19, and one that has been published in the scientific journals of the region. A search with the keyword "COVID-19" in the Scientific Electronic Library Online (SciELO) database resulted in the identification of 261 documents. Following PRISMA guidelines, the total number was reduced to 117 for the purpose of the bibliometric analysis (i.e., elimination of preprint duplicates). Such analysis resulted in the following findings: 69 publications were editorial or individual commentaries, and 48 were original articles. The male authors totaled 280, contrasted with 169 female authors. Two Brazilian journals led in the number of publications: Cadernos de Saúde Pública and Clinics. Even though the Latin American scientific productivity regarding COVID-19 is not well represented in the different databases of the region, it is expected that these scientific publications will achieve increased visibility in the coming months. The article emphasizes the importance of systematic and bibliographic reviews of the scientific literature in Latin America in order to evaluate the public health achievements of the region.
\end{abstract}

Keywords: COVID-19, review, scientific publications, bibliometrics, Latin America

\section{INTRODUCTION}

In the previous two decades several viral epidemics have challenged the health of the world population, including the severe acute respiratory syndrome (SARS), the strain of swine flu called H1N1, and the Middle East respiratory syndrome (MERS) (1,2). In December of 2019, reports of a new disease out of Wuhan, China began to circulate, this time caused by a novel coronavirus, SARS-CoV-2, and labelled COVID-19 (CO for corona, VI for virus, $\mathrm{D}$ for disease and 19 for the year it was identified) $(3,4)$. Since those initial reports, the virus has been found in 188 countries, infecting well over 6 million people and causing close to 400,000 deaths as of May 31, 2020 (source: https://coronavirus.jhu.edu/map.html). Of the total confirmed cases, death estimates range from $0.8 \%$ to $4.2 \%$, with a sizable majority comprised by older adults, those immunocompromised, or presenting chronic conditions (e.g., chronic lung disease, moderate to severe asthma, cardiac disease with complications, diabetes) (5).

People infected with SARS-CoV-2 may remain asymptomatic for up to five days, some may experience clinical symptoms within a week including dry cough, fever, headache, nasal congestion, and fatigue, while others may progress into severe COVID-19 symptoms such as septic shock, pulmonary edema, pneumonia, and respiratory failure $(6,7)$. Patients who experience the most severe symptoms of COVID-19 represent about $15 \%$ of all cases (8). Unfortunately, at this moment there is no proven and effective pharmacological treatment to cure the disease (9). Due to its high contagion potential and the exponential increase in its incidence, the World Health 


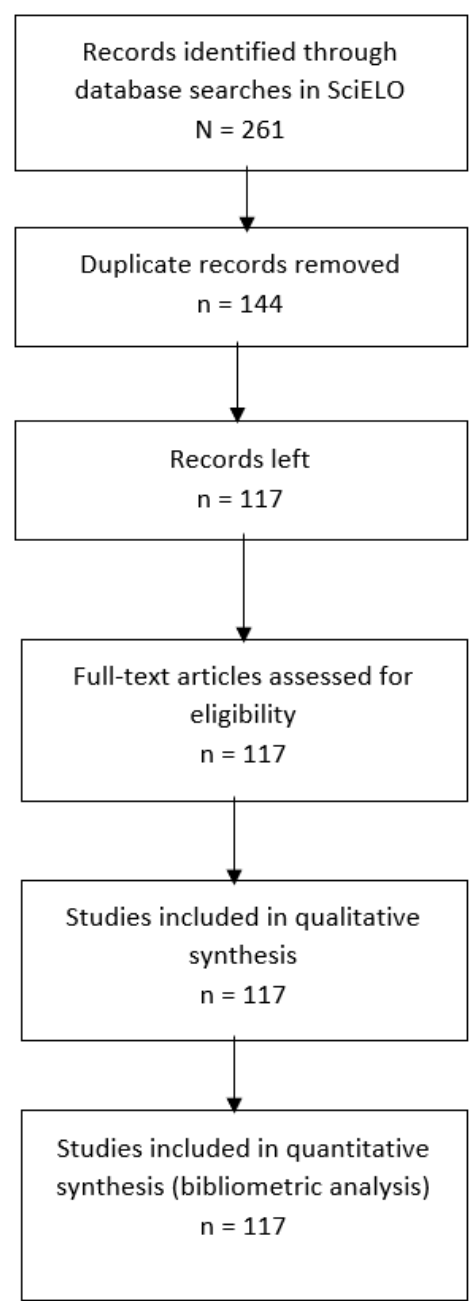

Figure 1. PRISMA

Organization (WHO) declared the COVID-19 a pandemic on March 11, 2020.

COVID-19 has not only had a global impact on various aspects of people's lives, the economy, governments, and societies, but it has also raised countless public health problems at the national, regional, and international levels. This has generated an important mobilization of human resources, assigned to address different aspects of the problems raised by COVID-19: from health personnel allocated to attend to the diverse needs of the population to thousands of scientists who are searching for different medical and social solutions.

Specifically, in the scientific field there has been what could be call an explosion of publications related to different aspects of COVID-19. In fact, there are already several systematic reviews and bibliometric studies that analyzes worldwide data (5,10-13). However, there are still no known studies focused on scientific publications in Latin America, let alone in the broad health field.

\section{METHOD}

The purpose of this article is in response to the need to provide an initial survey of publications on COVID-19 in Latin America, through a systematic review of the scientific literature that has been published thus far. To achieve this goal, an ex post facto bibliometric retrospective investigation was carried out (14), with analyses on two levels. In a first level, a general analysis of the scientific production as identified through Ibero-American databases is presented. A search for the keyword "COVID-19" in the databases SciELO, Redalyc, and Dialnet (15) was conducted; then the main characteristics of the resulting scientific publications were extracted, including type of publication, main used language, disciplinary fields, and country of origin, among others. The information obtained is presented and summarized through various visual aids.

At a second level, the information retrieved from the SCiELO database was used to perform a bibliometric analysis (16-18). Although 261 documents were identified via SciELO, the bibliometric analysis was based on the selection of 117 documents, following the Preferred Reporting Items for Systematic Reviews and Meta-Analyses (known as PRISMA: Figure 1) (19-20). Specifically, 144 documents were excluded because they were duplicates in the preprint stage.

\section{RESULTS}

At the first level of analysis, a search with the keyword "COVID-19" in the three regional scientific databases carried out on May 23, 2020 identified 747 documents, 479 in Dialnet, 261 in SciELO, and 7 in Redalyc. In contrast, 15,480 documents were identified in PubMed and 134,000 results in Google Scholar.

According to the analysis offered by Dialnet: 462 were articles, 12 book chapters, and 5 books. Most were in Spanish ( $n$ 442) and the rest in various languages. The documents were distributed in the following areas: legal sciences ( $n$ 191), health sciences ( $n 80)$, economics and business $(n 71)$, social sciences ( $n$ 64), psychology and education ( $n$ 54), humanities ( $n$ 35), basic and experimental sciences $n$ (27), food and agriculture ( $n$ 7 ), technologies ( $n 5)$, geosciences and environment ( $n 2)$, art ( $n$ 2 ) and biological sciences ( $n 1)$. The distribution by country showed: Spain ( $n$ 370), Italy ( $n 50)$, Venezuela ( $n$ 17), Cuba ( $n 11)$, Mexico ( $n$ 7), United States of America ( $n$ 7), Chile ( $n$ 5), Colombia ( $n$ 5), Germany ( $n$ 2), Canada ( $n$ 1), Costa Rica (n 1), Ecuador ( $n 1)$, France $(n 1)$ and Peru $(n 1)$.

Of the total documents recovered from SciELO (without the exclusion made later for bibliometric analysis), 142 were classified as articles, 43 editorials, 26 other, 22 quick communications, 14 letters, 7 review articles, 5 comment articles and 2 case reports (Figure 2). The languages of the publications were English ( $n$ 171), Portuguese ( $n$ 128) and Spanish (n 31); several documents appeared in two languages. According to the thematic areas from the Web of Science (WoS), the bulk of the publications were on health services, medicine, and public health (Figure 3 ). These data contrasted with the data obtained on Dialnet, where the documents in legal sciences doubled that of health.

It is important to note the set of journals that were at the top when it came to inclusion of content on COVID-19 (Figure 4). Most belonged to the field of medicine and its different specialties. Nonetheless, there was a second group of journals in areas that also belong to the health field, specifically psychiatry and psychology, yet address other specific aspects, such as mental health. Scientists and professionals in psychiatry and psychology are indeed making important contributions to the understanding of the COVID-19 pandemic (21-23). 


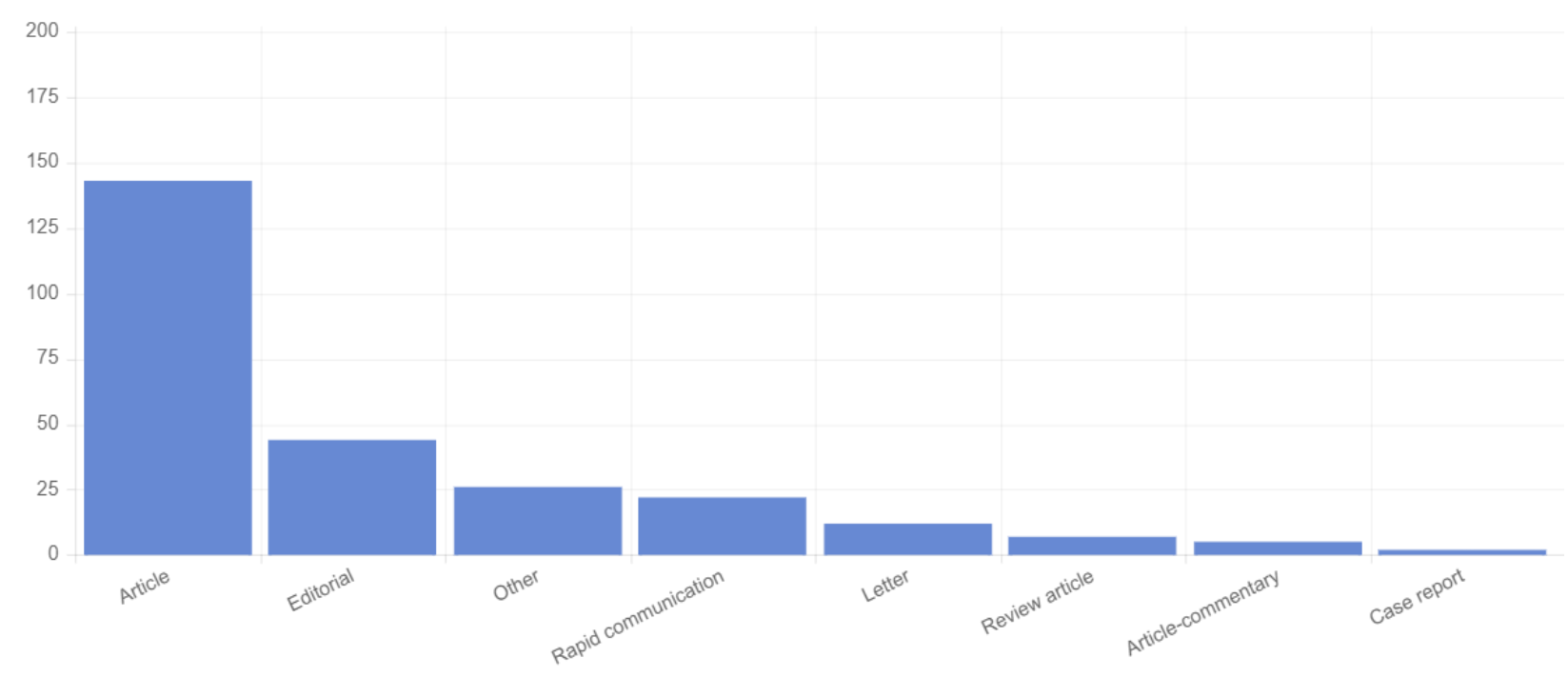

Figure 2. Types of Scientific Literature (261 documents)

Source: SciELO, May 23, 2020

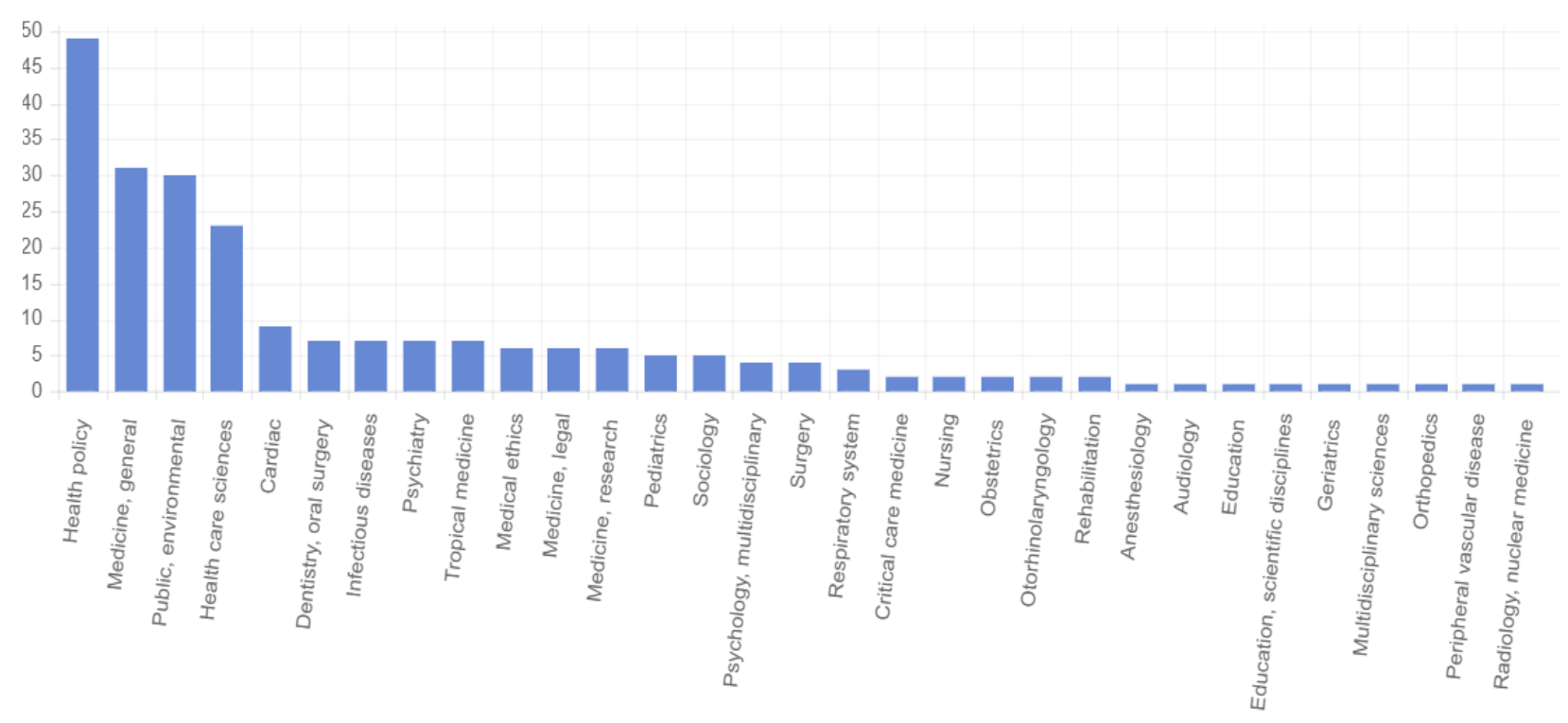

Figure 3. WoS Subject Categories (261 documents)

Source: SciELO, May 23, 2020

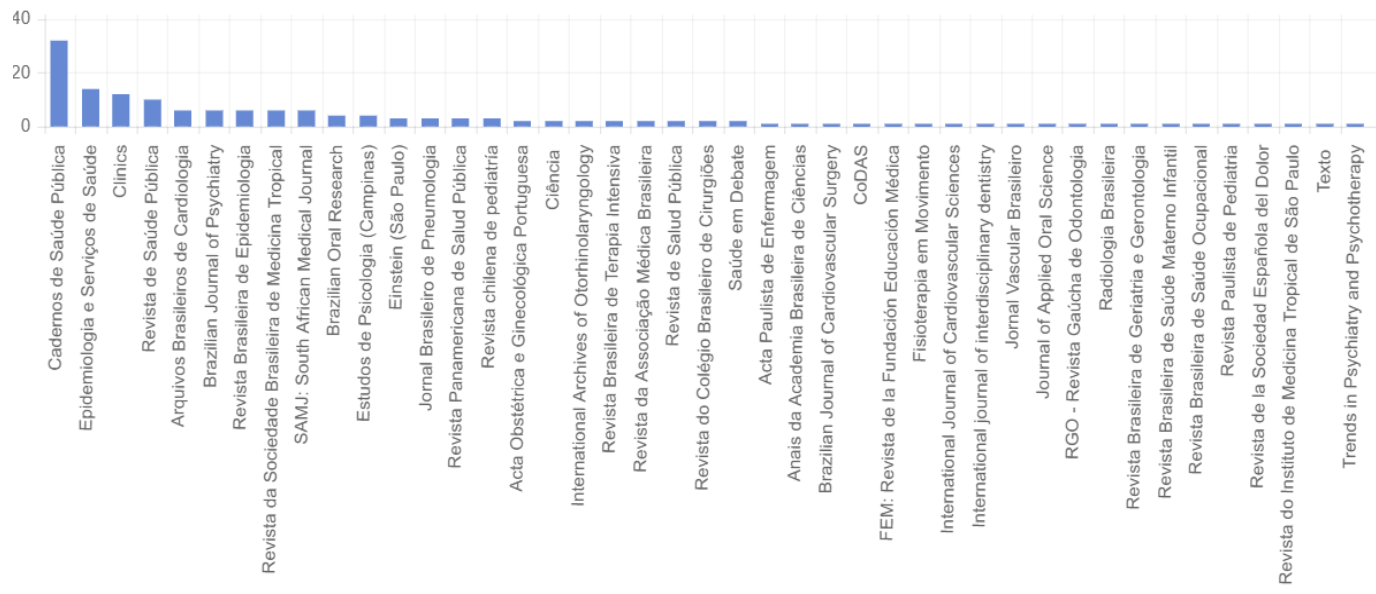

Figure 4. Journal (261 documents)

Source: SciELO, May 23, 2020 
Table 1. Scientific Publications on COVID-19

\begin{tabular}{|c|c|c|c|c|c|c|c|c|c|}
\hline \multirow{2}{*}{$\begin{array}{l}\text { Journal } \\
\text { Organization } \\
\text { Cadernos de Saúde Pública } \\
\text { Fundação Oswaldo Cruz }\end{array}$} & \multicolumn{2}{|c|}{ Country $\begin{array}{c}\text { All } \\
\text { Documents }\end{array}$} & \multicolumn{5}{|c|}{ Articles Editorials Comments All Authors Male } & \multicolumn{2}{|c|}{ emale References } \\
\hline & Brazil & 16 & 7 & 1 & 8 & 61 & 32 & 29 & 349 \\
\hline $\begin{array}{l}\text { Clinics } \\
\text { Universidade de São Paulo }\end{array}$ & Brazil & 12 & 5 & 4 & 3 & 62 & 39 & 23 & 264 \\
\hline $\begin{array}{l}\text { Epidemiologia e Serviços de Saúde } \\
\text { Ministério da Saúde do Brasil }\end{array}$ & Brazil & 7 & 5 & 2 & & 19 & 10 & 9 & 126 \\
\hline $\begin{array}{l}\text { Arquivos Brasileiros de Cardiologia } \\
\text { Sociedade Brasileira de Cardiologia }\end{array}$ & Brazil & 6 & 2 & 2 & 2 & 31 & 15 & 16 & 119 \\
\hline $\begin{array}{l}\text { Brazilian Journal of Psychiatry } \\
\text { Associação Brasileira de Psiquiatria } \\
\end{array}$ & Brazil & 6 & 3 & 2 & 1 & 21 & 12 & 9 & 74 \\
\hline $\begin{array}{l}\text { Revista da Sociedade Brasileira de Medicina } \\
\text { Tropical } \\
\text { Sociedade Brasileira de Medicina Tropical } \\
\end{array}$ & Brazil & 6 & 1 & 3 & 2 & 30 & 22 & 8 & 69 \\
\hline $\begin{array}{l}\text { South African Medical Journal (SAMJ) } \\
\text { Health and Medical Publishing Group }\end{array}$ & $\begin{array}{l}\text { South } \\
\text { Africa }\end{array}$ & 6 & & 6 & & 11 & 5 & 6 & 43 \\
\hline $\begin{array}{l}\text { Revista de Saúde Pública } \\
\text { Universidade de São Paulo }\end{array}$ & Brazil & 5 & 3 & 1 & 1 & 15 & 9 & 6 & 73 \\
\hline $\begin{array}{l}\text { Brazilian Oral Research } \\
\text { Sociedade Brasileira de Pesquisa Odontológica }\end{array}$ & Brazil & 4 & 4 & & & 18 & 9 & 9 & 174 \\
\hline $\begin{array}{l}\text { Estudos de Psicologia } \\
\text { Pontifícia Universidade Católica de Campinas }\end{array}$ & Brazil & 4 & 4 & & & 17 & 6 & 11 & 138 \\
\hline $\begin{array}{l}\text { Revista Brasileira de Epidemiologia } \\
\text { Associação Brasileira de Saúde Coletiva }\end{array}$ & Brazil & 3 & 1 & 2 & & 13 & 8 & 5 & 35 \\
\hline $\begin{array}{l}\text { Einstein } \\
\text { Instituto Israelita de Ensino e Pesquisa Albert Einstein }\end{array}$ & Brazil & 3 & 1 & 1 & 1 & 29 & 22 & 7 & 37 \\
\hline $\begin{array}{l}\text { Jornal Brasileiro de Pneumologia } \\
\text { Sociedade Brasileira de Pneumologia e Tisiologia }\end{array}$ & Brazil & 3 & 1 & 1 & 1 & 14 & 14 & & 22 \\
\hline $\begin{array}{l}\text { Revista Panamericana de Salud Pública } \\
\text { Organización Panamericana de la Salud }\end{array}$ & USA & 3 & 1 & 2 & & 9 & 6 & 3 & 72 \\
\hline $\begin{array}{l}\text { Revista Chilena de Pediatría } \\
\text { Sociedad Chilena de Pediatría }\end{array}$ & Chile & 3 & & 3 & & 4 & 4 & & 19 \\
\hline Others & & 30 & 10 & 20 & & 95 & 67 & 28 & 463 \\
\hline Total & & 117 & 48 & 50 & 19 & 449 & 280 & 169 & 2077 \\
\hline
\end{tabular}

The second level of analysis, shown on Table 1, specifies the distribution of findings from the bibliometric review following the selection of the 117 documents related to COVID19 , published in scientific journals. Some results obtained from the SCiELO database are altered in it, but the prominence of certain health journals remains. According to authors' affiliation, the majority belonged to universities, but also to foundations, scientific societies, and public health agencies. In general, the authors belonged to the institutional sphere that publishes the journal.

An analysis of the distribution by type of documents indicated a significant lower number of articles, reviews and brief communications when compared to all editorial contributions (editorials and letters to the editor) and comments (notes and comments). With respect to authors, the number of males (62\%) exceeded females (38\%), or close to a ratio of $2 / 3$ to $1 / 3$. Considering the sex of the first author of the 117 documents, $86(73 \%)$ were males and 31 (27\%) females, or close to a ratio of $3 / 4$ to $1 / 4$. When all types of documents were considered, on average, each document included 18 references.

Following the WoS classification of academic papers, and a general assessment of the publications, the vast majority of documents were theoretical in nature, and to a lesser extent, empirical reports and case studies. Many consisted of analysis of health measures and policies, some focused on the analysis of epidemiological data and others addressed various areas of medicine, including surgery, cardiology, physical therapy, psychiatry, and dentistry.
Regarding the diagnosis of COVID-19, several studies suggested the importance of Chest Computed Tomography as an indicator of the disease, but not as a confirmatory test by itself $(24,25)$. Pre-existing cardiovascular conditions were the focus of attention in several publications (26) and also the importance attributed to physical activity as a health affirming and disease prevention measure (27-29). Several articles concentrated on the analysis of the health measures and care that must be taken when treating dental patients $(30,31)$, as well as on the protection measures of the health personnel involved in the care of patients with COVID-19 (32-34).

Considering contextual factors in a world characterized by the presence of SARS-CoV-2, some publications indicated that the use of certain non-pharmacological interventions (such as social distancing, wearing face masks, and banning crowd gatherings, among others) had been shown to be effective in reducing the spread of the virus $(35,36)$. Other contributions focused on mapping geographical areas where populations vulnerable to COVID-19 were concentrated (37) and on estimating possible demands for intensive care units (38).

In the field of mental health, the publications not only highlighted the importance of continuing with psychological and psychiatric treatment $(39,40)$, but also raised the need to pay more attention to the emotional effects caused by the pandemic (41-43). Various articles underscored the need to update and systematize the psychological literature in order to offer relevant interventions and recommendations (44).

Several systematic reviews of the scientific literature were also identified; the objectives of those reviews were to retrieve 
the best information available on a particular topic, and thus be able to guide decision-making while establishing specific recommendations. Some examples include matters pertaining to medical surgeries (45), the counseling of mothers of newborns who have been diagnosed or suspected of contagion (46), the care of children and critically ill adolescents (47), the greater susceptibility of older adults to contract the disease (48), and clinical trials of various drugs used to combat the effects of COVID-19 (49).

\section{DISCUSSION}

Latin American publications on COVID-19 are not yet sufficiently represented in international and regional scientific databases. The three databases analyzed contain some inclusion biases. SciELO, with its origin in Brazil, contains a predominance of scientific literature in Portuguese over that in Spanish, therefore, Brazilian publications are better represented than other Latin American publications in Spanish. Dialnet, originating in Spain, contains a predominance of publications in the Spanish language, with special coverage of publications from Spain. For its part, the scarcity of data available in Redalyc (origin in Mexico) at the moment, does not support further analysis of productivity on COVID-19 through that database.

In spite of these challenges, it has been possible to establish a preliminary map of the scientific publications on COVID-19 and the different scientific journals that are addressing the pandemic the most, at least in their first issues in 2020. Two Brazilian medical journals are among the most productive, although other journals that have already published various articles on COVID-19 were also found. The participation of female authors seems to be somewhat neglected, as some studies have suggested internationally (50).

A general characteristic of the publications is their short length, since they tend to address a particular aspect of health policy or a specific result. At the moment, there are very few scientific articles reporting on a study while brief communications, editorials and comments tend to dominate the overall number of publications. The documents are mainly based on theoretical reflections on health policies and health services, while others articulated the need to propose concrete actions in different areas of health. This specific finding can be explained by the novel and recent nature of the disease and the sizable length of time it takes to carry out scientific research as well as to publish scientific articles, including the peer review process.

The present study can serve as a contrasting record to anticipated future studies, both regionally and internationally. In addition, it should be complemented with the information derived from the financing and execution of research projects that each country has carried out as a scientific policy measure to encourage the study of COVID-19. Several Latin American countries have put out calls for various specialty research programs and has disbursed public and private funds for such projects. It is expected that in the medium term the results and scientific contributions expected to come out of such endeavors will begin to appear and be disseminated in the scientific literature. Once that happens, it is anticipated that such publications will be reflected, eventually, in the scientific databases, including those analyzed in this article.

\section{CONCLUSION}

The scientific and professional communities are addressing, to various extents, the public health matters brought about by the COVID-19 pandemic. These matters include the general public policies of each country, the direct treatment of patients diagnosed with COVID-19, and the consequences of the abrupt modifications of daily life (social, psychological, and economic), with all the risks that this entails.

Considering the novelty of COVID-19, it is necessary to carry out periodic evaluations of scientific publications to assess the progress made and the areas not covered by the multiple disciplines represented in the databases analyzed for this study. These periodic evaluations can guide the rethinking of scientific data and the reformulation of research problems in each area of scientific knowledge.

\section{REFERENCES}

1. Cascella M, Rajnik M, Cuomo A, Dulebohn SC, Di Napoli R. Features, evaluation and treatment coronavirus (COVID19). Statpearls [internet]: StatPearls Publishing; 2020.

2. Werneck GL, Carvalho MS. A pandemia de COVID-19 no Brasil: crônica de uma crise sanitária anunciada. Cadernos de Saúde Pública. 2020;36(5). https://doi.org/10.1590/ 0102-311x00068820

3. Huang C, Wang Y, Li X, Ren L, Zhao J, Hu Y, et al. Clinical features of patients infected with 2019 novel coronavirus in Wuhan, China. Lancet. 2020;395(10223):497-506. https://doi.org/10.1016/S0140-6736(20)30183-5 PMID:31986264

4. Wu F, Zhao S, Yu B, Chen Y-M, Wang W, Song Z-G, et al. A new coronavirus associated with human respiratory disease in China. Nature. 2020;579(7798):265-9. https://doi.org/10.1038/s41586-020-2008-3 PMID:32015508

5. Chahrour M, Assi S, Bejjani M, Nasrallah AA, Salhab H, Fares $M$, et al. A Bibliometric Analysis of COVID-19 Research Activity: A Call for Increased Output. Cureus. 2020;12(3):e7357-e. https://doi.org/10.7759/cureus.7357 PMID:32328369

6. Velavan TP, Meyer CG. The COVID-19 epidemic. Trop Med Int Health. 2020;25(3):278-80. Epub 2020/02/16. https://doi.org/10.1111/tmi.13383 PMID:32052514

7. Yang X, Yu Y, Xu J, Shu H, Xia Ja, Liu H, et al. Clinical course and outcomes of critically ill patients with SARS-CoV-2 pneumonia in Wuhan, China: a single-centered, retrospective, observational study. Lancet Respir Med. 2020;8(5):475-81. Epub 2020/02/24. https://doi.org/ 10.1016/S2213-2600(20)30079-5 PMID:32105632

8. Wu Z, McGoogan JM. Characteristics of and Important Lessons from the Coronavirus Disease 2019 (COVID-19) Outbreak in China. JAMA. 2020;323(13):1239. https://doi.org/10.1001/jama.2020.2648

9. Cortegiani A, Ingoglia G, Ippolito M, Giarratano A, Einav S. A systematic review on the efficacy and safety of chloroquine for the treatment of COVID-19. Journal of critical care. 2020;57:279-83. Epub 2020/03/17. https://doi.org/10.1016/ j.jcrc.2020.03.005 PMID:32173110 
10. Harapan H, Itoh N, Yufika A, Winardi W, Keam S, Te H, et al. Coronavirus disease 2019 (COVID-19): A literature review. J Infect Public Health. 2020;13(5):667-73. Epub 2020/04/08. https://doi.org/10.1016/j.jiph.2020.03.019 PMID:32340833

11. O 'Brien N, Barboza-Palomino M, Ventura-León J, CaychoRodríguez T, Sandoval-Díaz JS, López-López W, et al. Nuevo coronavirus (COVID-19). Un análisis bibliométrico. Revista Chilena de Anestesia. 2020;49(3):408-15. https://doi.org/10.25237/revchilanestv49n03.020

12. Škorić L, Glasnović A, Petrak J. A publishing pandemic during the COVID-19 pandemic: how challenging can it become? Croatian Medical Journal. 2020;61(2):79-81.

13. Torres-Salinas D. Ritmo de crecimiento diario de la producción científica sobre Covid-19. Análisis en bases de datos y repositorios en acceso abierto. El profesional de la información. 2020;29(2):e290215. https://doi.org/10.3145/ epi.2020.mar.15

14. Montero I, León OG. A guide for naming research studies in Psychology. International Journal of clinical and Health psychology. 2007;7(3):847-62.

15. Santillán-Aldana J. La necesidad de sistemas de información abiertos no excluyentes: Entrevista a Ana María Cetto Kramis. Biblios: Journal of Librarianship and Information Science. 2011(42):59-62. https://doi.org/ 10.5195/biblios.2011.11

16. Gallegos M, Pérez-Acosta A, Klappenbach H, López López W, Bregman C. Los estudios bibliométricos en el campo de la psicología en Iberoamérica: una revisión metabibliométrica. Interdisciplinaria. 2020;37(2).

17. López P. Introducción a la bibliometría. Valencia: Promolibro; 1996.

18. Zupic I, Čater T. Bibliometric Methods in Management and Organization. Organizational Research Methods. 2014;18(3):429-72. https://doi.org/10.1177/1094428114562 629

19. González de Dios J, Buñuel Álvarez JC, Aparicio Rodrigo M. Listas guía de comprobación de revisiones sistemáticas y metaanálisis: declaración PRISMA. Evidencias en pediatría. 2011;7(4):20.

20. Vidal EldO. O que esperamos das revisões sistemáticas no futuro. Cadernos de Saúde Pública. 2016;32(9). https://doi.org/10.1590/0102-311xed010916

21. Gallegos M, Zalaquett C, Luna Sánchez SE, Mazo-Zea R, Ortiz-Torres B, Penagos-Corzo JC, et al. Cómo afrontar la pandemia del Coronavirus (Covid-19) en las Américas: recomendaciones y líneas de acción sobre salud mental. Revista Interamericana de Psicología/Interamerican Journal of Psychology. 2020;54(1):e1304. https://doi.org/ 10.30849/ripijp.v54i1.1304

22. Holmes EA, O'Connor RC, Perry VH, Tracey I, Wessely S, Arseneault $L$, et al. Multidisciplinary research priorities for the COVID-19 pandemic: a call for action for mental health science. The lancet Psychiatry. 2020;7(6):547-60. https://doi.org/10.1016/S2215-0366(20)30168-1 PMID:32304649

23. Nations U. Policy brief: COVID-19 and the need for actions on mental health2020. Available at: https://www.un.org/ sites/un2.un.org/files/un_policy_brief-covid_and_mental _health_final.pdf
24. Chate RC, Fonseca E, Passos RBD, Teles G, Shoji H, Szarf G. Presentation of pulmonary infection on CT in COVID-19: initial experience in Brazil. Jornal brasileiro de pneumologia : publicacao oficial da Sociedade Brasileira de Pneumologia e Tisilogia. 2020;46(2):e20200121. https://doi.org/10.36416/1806-3756/e20200121 PMID:32294718

25. Shoji H, Fonseca EKUN, Teles GBdS, Passos RBD, Yanata E, Silva MMA, et al. Structured thoracic computed tomography report for COVID-19 pandemic. Einstein (Sao Paulo). 2020;18:eED5720-eED. https://doi.org/10.31744/ einstein_journal/2020ED5720 PMID:32294704

26. Ferrari F. COVID-19: Dados Atualizados e sua Relação Com - Sistema Cardiovascular. Arquivos Brasileiros de Cardiologia. 2020. https://doi.org/10.36660/abc.20200215

27. Ferreira MJ, Irigoyen MC, Consolim-Colombo F, Saraiva JFK, De Angelis K. Vida Fisicamente Ativa como Medida de Enfrentamento ao COVID-19. Arquivos Brasileiros de Cardiologia. 2020. https://doi.org/10.36660/abc.20200235

28. Souza Filho BABd, Tritany ÉF. COVID-19: importância das novas tecnologias para a prática de atividades físicas como estratégia de saúde pública. Cadernos de Saúde Pública. 2020;36(5). https://doi.org/10.1590/0102-311x00054420

29. Stein R. Exercício Físico em Pacientes Cardiopatas e na População em Tempos de Coronavírus. Arquivos Brasileiros de Cardiologia. 2020;114(5):827-8. https://doi.org/10.36660/abc.20200281

30. González-Olmo MJ, Ortega-Martínez AR, Delgado-Ramos B, Romero-Maroto M, Carrillo-Diaz M. Perceived vulnerability to Coronavirus infection: impact on dental practice. Brazilian Oral Research. 2020;34:e044. https://doi.org/10.1590/1807-3107bor-2020.vol34.0044

31. Pereira LJ, Pereira CV, Murata RM, Pardi V, Pereira-Dourado SM. Biological and social aspects of Coronavirus Disease 2019 (COVID-19) related to oral health. Brazilian Oral Research. 2020;34:e041. https://doi.org/10.1590/18073107bor-2020.vol34.0041

32. Kulcsar MA, Montenegro FL, Arap SS, Tavares MR, Kowalski LP. High Risk of COVID-19 Infection for Head and Neck Surgeons. Int Arch Otorhinolaryngol. 2020;24(2):e129-e30. https://doi.org/10.1055/s-0040-1709725 PMID:32296469

33. Medeiros EAS. A luta dos profissionais de saúde no enfrentamento da COVID-19. Acta Paulista de Enfermagem. 2020;33. https://doi.org/10.37689/acta-ape/2020edt0003

34. Ornell F, Halpern SC, Kessler FHP, Narvaez JCdM. The impact of the COVID-19 pandemic on the mental health of healthcare professionals. Cadernos de Saúde Pública. 2020;36(4). https://doi.org/10.1590/0102-311x00063520

35. Garcia LP. Uso de máscara facial para limitar a transmissão da COVID-19. Epidemiologia e Serviços de Saúde. 2020;29(2). https://doi.org/10.5123/s1679-4974202000020 0021

36. Garcia LP, Duarte E. Intervenções não farmacológicas para o enfrentamento à epidemia da COVID-19 no Brasil. Epidemiologia e Serviços de Saúde. 2020;29(2). https://doi.org/10.5123/s1679-49742020000200009

37. Santos JPCd, Siqueira ASP, Praça HLF, Albuquerque HG. Vulnerabilidade a formas graves de COVID-19: uma análise intramunicipal na cidade do Rio de Janeiro, Brasil. Cadernos de Saúde Pública. 2020;36(5). https://doi.org/10.1590/0102-311×00075720 
38. Moreira RdS. COVID-19: unidades de terapia intensiva, ventiladores mecânicos e perfis latentes de mortalidade associados à letalidade no Brasil. Cadernos de Saúde Pública. 2020;36(5). https://doi.org/10.1590/0102-311x 00080020

39. Castro REVd, Garcez FB, Avelino-Silva TJ. Patient care during the COVID-19 pandemic: do not leave delirium behind. Brazilian Journal of Psychiatry. 2020. https://doi.org/10.1590/1516-4446-2020-1048

40. Correa H, Malloy-Diniz LF, da Silva AG. Why psychiatric treatment must not be neglected during the COVID-19 pandemic. Brazilian Journal of Psychiatry. 2020. https://doi.org/10.1590/1516-4446-2020-0995

41. Do Bú EA, Alexandre MESd, Bezerra VAdS, Sá-Serafim RCdN, Coutinho MdPdL. Representações e ancoragens sociais do novo coronavírus e do tratamento da COVID-19 por brasileiros. Estudos de Psicologia (Campinas). 2020;37. https://doi.org/10.1590/1982-0275202037e200073

42. Ornell F, Schuch JB, Sordi AO, Kessler FHP. "Pandemic fear" and COVID-19: mental health burden and strategies. Braz J Psychiatry. 2020;42(3):232-5. https://doi.org/10.1590/15164446-2020-0008 PMID:32267343

43. Serafim AdP, Gonçalves PD, Rocca CC, Lotufo Neto F. The impact of COVID-19 on Brazilian mental health through vicarious traumatization. Brazilian Journal of Psychiatry. 2020. https://doi.org/10.1590/1516-4446-2020-0999

44. Schmidt B, Crepaldi MA, Bolze SDA, Neiva-Silva L, Demenech L. Saúde mental e intervenções psicológicas diante da pandemia do novo coronavírus (COVID-19). Estudos de Psicologia (Campinas). 2020;37:e200063. https://doi.org/10.1590/1982-0275202037e200063
45. Hojaij FC, Chinelatto LA, Boog GHP, Kasmirski JA, Lopes JVZ, Sacramento FM. Surgical Practice in the Current COVID-19 Pandemic: A Rapid Systematic Review. Clinics (Sao Paulo). 2020;75:e1923-e. Epub 2020/05/15. https://doi.org/10.6061/clinics/2020/e1923 PMID:32428115

46. Carvalho WBd, Gibelli MABC, Krebs VLJ, Calil VMLT, Johnston C. Expert recommendations for the care of newborns of mothers with COVID-19. Clinics (Sao Paulo). 2020;75:e1932-e. https://doi.org/10.6061/clinics/2020/ e1932 PMID:32428112

47. Carlotti APdCP, Carvalho WBd, Johnston C, Rodriguez IS, Delgado AF. COVID-19 Diagnostic and Management Protocol for Pediatric Patients. Clinics (Sao Paulo). 2020;75:e1894-e. https://doi.org/10.6061/clinics/2020/ e1894 PMID:32321116

48. Peron JPS, Nakaya H. Susceptibility of the Elderly to SARSCoV-2 Infection: ACE-2 Overexpression, Shedding, and Antibody-dependent Enhancement (ADE). Clinics (Sao Paulo). 2020;75:e1912-e. https://doi.org/10.6061/clinics/ 2020/e1912 PMID:32428113

49. Rosa SGV, Santos WC. Clinical trials on drug repositioning for COVID-19 treatment. Revista Panamericana de Salud Pública. 2020;44:e40. https://doi.org/10.26633/RPSP.2020. 40

50. Viglione G. Are women publishing less during the pandemic? Here's what the data say. Nature. 2020;581(7809):365-6. https://doi.org/10.1038/d41586-020 $-01294-9$ 